\title{
Profile of facial trauma in older adults cared for at a tertiary hospital of the Brazilian Federal District
}

\author{
Perfil do trauma de face em idosos atendidos em \\ Hospital terciário do Distrito Federal
}

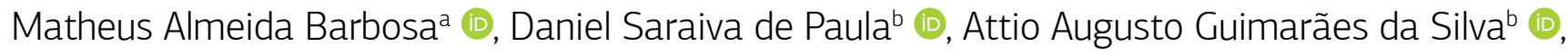 \\ Leonardo Paiva Marques de Souza ${ }^{(\mathbb{D}}$, Isabela Gomes de Sena Ribeiro ${ }^{(0)}$, \\ Everton Luis Santos da Rosab ${ }^{(\mathbb{D}}$, Alexandre Franco Miranda ${ }^{\mathbb{D}}$, Lucy de Oliveira Gomes ${ }^{\mathrm{a}}$
}

OBJECTIVES: The phenomenon of population aging and the remarkable inclusion of older adults in the economically active population has increased their participation in injuries and accidents, including facial trauma. The purpose of this study was to analyze the prevalence, etiology, and treatment of facial trauma in the older population of the Brazilian Federal District, as well as the gender, etiology, type of trauma, and treatment strategy regarding different age groups (60-69 years, 70-79 years, and 80 years or older). METHODS: This is a retrospective quantitative descriptive study using electronic medical records (Trackcare system) of older patients (aged $\geq 60$ years) assisted at the Emergency Department of a tertiary hospital of the Federal District between 2016 and 2017 due to facial trauma. RESULTS: Out of 2382 records of patients with facial trauma, 139 (5.8\%) were aged over 60 years. The main causes of facial trauma were falls, both in male and female patients. Facial contusion was the main diagnosis of facial trauma (25.2\%), followed by fractures of the jaw (16.5\%) and zygomatic complex (15.8\%). Conservative treatment was the most common strategy adopted in the Emergency Department of Oral and Maxillofacial Surgery and Traumatology. CONCLUSIONS: This study showed a high prevalence of facial trauma in the geriatric population. Etiological factors such as falls and car accidents were highlighted in the studied groups. Conservative treatment and local guidelines were the preferred therapeutic approaches. Owing to the growth trend of the older population in the upcoming decades, exposure to risk factors for facial trauma tends to grow, thus requiring greater attention and specific knowledge from health professionals. KEYWORDS: trauma; older adult; fracture.

OBJETIVO: O envelhecimento da população e a inclusão marcante dos idosos na parcela economicamente ativa vêm aumentando a participação deles em traumatismos e acidentes, incluindo os que ocorrem na face. O objetivo deste trabalho foi analisar a prevalência, a etiologia e o tratamento do traumatismo de face na população idosa do Distrito Federal, assim como nas diferentes faixas etárias (60 - 69, 70 - 79 e 80 e mais), em relação a sexo, etiologia, tipo de trauma e tratamento. METODOLOGIA: Trata-se de estudo retrospectivo descritivo quantitativo, que utilizou prontuários eletrônicos (Sistema Trackcare) de pacientes idosos ( $\geq 60$ anos) atendidos no pronto-socorro de hospital terciário do Distrito Federal, durante os anos de 2016 e 2017, por traumatismo de face. RESULTADOS: Do total de 2.382 prontuários de pacientes com traumatismo de face, 139 (5,8\%) foram de idosos. 0 principal fator responsável pelo traumatismo na face foi a queda, tanto no sexo masculino como no feminino. A contusão na face foi o principal diagnóstico de traumatismo nessa região (25,2\%), seguido por fratura de mandíbula (16,5\%) e fratura do complexo zigomático (15,8\%). O tratamento conservador foi o mais adotado no serviço de pronto-socorro de Cirurgia e Traumatologia Bucomaxilofacial. CONCLUSÕES: O presente estudo evidenciou uma elevada prevalência de traumas de face na população geriátrica. Fatores etiológicos como quedas e acidentes automobilísticos tiveram destaques nos grupos estudados. O tratamento conservador e orientações locais foram as condutas terapêuticas adotadas preferencialmente. Devido à tendência de crescimento da população idosa nas próximas décadas, bem como o perfil ativo que os idosos estão assumindo, a exposição a fatores de risco para traumas faciais tende a crescer, exigindo-se assim maior atenção e conhecimento específico por parte dos profissionais de saúde..

PALAVRAS-CHAVE: traumatismo; idoso; fratura.

a Universidade Católica de Brasília - Brasília (DF), Brazil.

'Department of Oral and Maxillofacial Surgery, Instituto Hospital de Base do Distrito Federal - Brasília (DF), Brazil.

Correspondence data

Matheus Almeida Barbosa - Universidade Católica de Brasília - QS 7 LOTE 1 - Taguatinga - Brasília (DF), Brazil. E-mail: matheusbarbosa1313@gmail.com Received on: 06/17/2021. Accepted on: 10/05/2021

How to cite this article: Barbosa MA, Paula DS, Silva AAG, Souza LPM, Ribeiro IGS, Rosa ELS, Miranda AF, Gomes LO. Profile of facial trauma in older adults cared for at a tertiary hospital of the Brazilian Federal District. Geriatr Gerontol Aging. 2021;15:e0210052. https://doi.org/10.53886/gga.e0210052 https://doi.org/10.53886/gga.e0210052 


\section{INTRODUCTION}

A significant increase in life expectancy has occurred in recent years. ${ }^{1}$ Brazil also undergoes a population aging process, being the sixth country with the highest aging rate worldwide. ${ }^{2}$

The inclusion of older people in the economically active population has increased the participation of this age group in trauma and accidents. ${ }^{3}$ Moura et al..$^{4}$ observed an increase in the incidence of facial trauma in older adults over the last decades. ${ }^{5}$ This age group is currently more exposed to the aggressive agents of modern life, thus becoming targets for countless types of trauma, including those of the maxillofacial region. ${ }^{6}$

In this sense, the increase in the number of older adults with facial trauma is notorious. In a cross-sectional quantitative analytical study performed at Instituto Doutor José Frota (a public trauma hospital located in Fortaleza [CE], Brazil), out of 280 older adults hospitalized with trauma in 2011, 47 had oral and maxillofacial trauma, with a prevalence of $16.8 \%{ }^{7}$ This trauma prevalence is similar to the $15.2 \%$ found for the facial area in studies by Yildiz et al. ${ }^{8}$

With regard to the etiology of these injuries in older adults, falls appear to be the main cause, differing from young people whose traumas are predominantly related to physical aggression and traffic accidents. ${ }^{7}$ Yildiz et al..$^{8}$ and Toivari et al. ${ }^{9}$ described, as possible explanations for these injuries in older adults, the decrease in proprioception, muscle weakness, tremors, decreased defensive reflexes, use of psychotropic drugs, and other systemic pathologies that are common in this age group. In association with these conditions, Pham-Dang et al. ${ }^{10}$ cited as aggravating factors the exposure of the face and head to physical injuries, falls, car accidents, and violence, as this population is considered vulnerable from the biological and social point of view.

In addition to these facts, aging is related to physiological changes in basal metabolism and to decreased cardiac, pulmonary, and renal functions, among others. This leads to a worse prognosis for older patients with trauma or undergoing small or medium-sized surgical procedures, and even more often to adverse reactions to medications and complications when systemic conditions are not stabilized. ${ }^{11}$

Conservative treatment was the main therapeutic choice, based mainly on issues inherent to surgical risk, but also on physiological issues related to older patients, especially when associated with chronic diseases that increase operative morbidity in open surgeries for reducing and fixing facial fractures. ${ }^{6,12,13}$ Barber ${ }^{14}$ highlights functional issues as a fundamental criterion to determine more invasive surgical procedures, since older people tend not to be concerned with problems related to facial aesthetics.

In this context, a broad knowledge of the etiology, incidence, and prevalence of trauma of the maxillomandibular complex in the older population is essential. Also important is the regional epidemiological profile, in order to verify the demand and establish a protocol for the initial care of older patients, suggesting changes in the standard of care and guiding rules for future prevention norms that follow the dynamism of society. ${ }^{13}$

The goal of this study was to analyze the prevalence, etiology, and treatment of facial trauma in the older population treated at the Emergency Department of Instituto Hospital de Base do Distrito Federal (IHBDF) during 2016 and 2017, as well as the gender, etiology, type of trauma, and treatment regarding different age groups (60-69 years, 70-79 years, and 80 years or older).

\section{METHODS}

This is a retrospective descriptive quantitative study of facial trauma in the older population (aged 60 years or over) cared for at the Emergency Department of a tertiary hospital of the Brazilian Federal District in 2016 and 2017. This study conducted a descriptive analysis of standard electronic medical records of the Trackcare system of the Federal District State Health Department (Secretaria de Estado de Saúde do Distrito Federal [SES-DF]) .

The sample of this study included 139 clinical cases. The medical records of 2384 older patients with facial trauma treated at the Emergency Department were analyzed. Inclusion criteria were: patients aged 60 years or older, assisted at the Emergency Department of Oral and Maxillofacial Surgery and Traumatology at IHBDF throughout 2016 and 2017, with a confirmed diagnosis of facial trauma and duly filled electronic medical records. Exclusion criteria were: attendees who did not have complete medical records (anamnesis and general data) and no ICD (International Classification of Diseases) classification.

Data were collected by accessing the standard Trackcare system of SES-DF; these were then treated and analyzed using GraphPad Prism 7. After verifying the frequency distribution (\%) in our sample, data were categorized into 3 different age groups: 60-69 years, 70-79 years, and > 80 years. In addition to the age groups, the study compared differences between genders (female vs male). This work was approved by the ethics committee of IHBDF (Certificate of Presentation for Ethical Appreciation [CAAE] No.02.172.918.430.018.153), according to Resolutions No. 466/2012 and 510/2016 of the National Health Council.

\section{RESULTS}

In order to estimate the prevalence and obtain information on oral and maxillofacial trauma in older adults, 2384 
medical records of patients with facial trauma treated at IHBDF in 2016 and 2017 were analyzed. After applying the aforementioned inclusion and exclusion criteria, our sample consisted of 139 cases. Older people comprised 5.8\% of all patients cared for at the Department, of which 87 (65.5\%) were male and $52(37.5 \%)$ were female.

Figure 1 shows the etiology of facial trauma in the older population in 2016 and 2017. Falls were the most frequent causal factor, even considering other factors, for both men and women. On the other hand, men presented aggressions and car accidents with a considerable frequency in relation to other etiological agents.

Table 1 shows that these 2 years of research within the older population are mostly represented by injuries by contusion, fractures of the mandible and zygomaticomaxillary complex, and laceration of soft tissues. Table 2 illustrates differences between the age groups, indicating that the younger the patient, the greater the variation in trauma, especially in women.

Table 3 shows contusions as the most frequent type of facial injury in male and female patients and in all age groups. According to Table 3, fractures of the zygomaticomaxillary complex and facial contusions were accentuated in the older age groups.

Table 4 shows a pattern of conservative treatment following guidelines as the strategy with the highest prevalence in all age groups. Conservative treatment was the main therapeutic choice, based mainly on issues inherent to surgical risk.
Table 1. Type of trauma to the face (general = year and gender).

\begin{tabular}{l|c|c}
\hline Fracture type & $\mathrm{n}$ & $\%$ \\
\hline Facial contusion & 35 & 25.18 \\
\hline Mandible fracture & 23 & 16.54 \\
\hline $\begin{array}{l}\text { Fracture of the } \\
\text { zygomaticomaxillary complex }\end{array}$ & 22 & 15.82 \\
\hline Laceration of soft tissues & 13 & 9.36 \\
\hline Zygomatic arch fracture & 10 & 7.20 \\
\hline Maxillary fracture & 9 & 6.48 \\
\hline Dentoalveolar trauma & 6 & 4.31 \\
\hline $\begin{array}{l}\text { Fracture of the zygomatic } \\
\text { complex + orbit }\end{array}$ & 4 & 2.88 \\
\hline Orbit fracture & 4 & 2.88 \\
\hline Frontal fracture & 4 & 2.88 \\
\hline $\begin{array}{l}\text { Fracture of the maxilla }+ \\
\text { zygomaticomaxillary complex }\end{array}$ & 3 & 2.16 \\
\hline $\begin{array}{l}\text { Fracture of the mandible }+ \\
\text { zygomaticomaxillary complex }\end{array}$ & 2 & 1.43 \\
\hline Fracture of the mandible + maxilla & 1 & 0.72 \\
\hline Panfacial fracture & 1 & 0.72 \\
\hline Abrasion & 1 & 0.72 \\
\hline Burn & 139 & 0.72 \\
\hline Total & & 100 \\
\hline & & \\
\hline
\end{tabular}

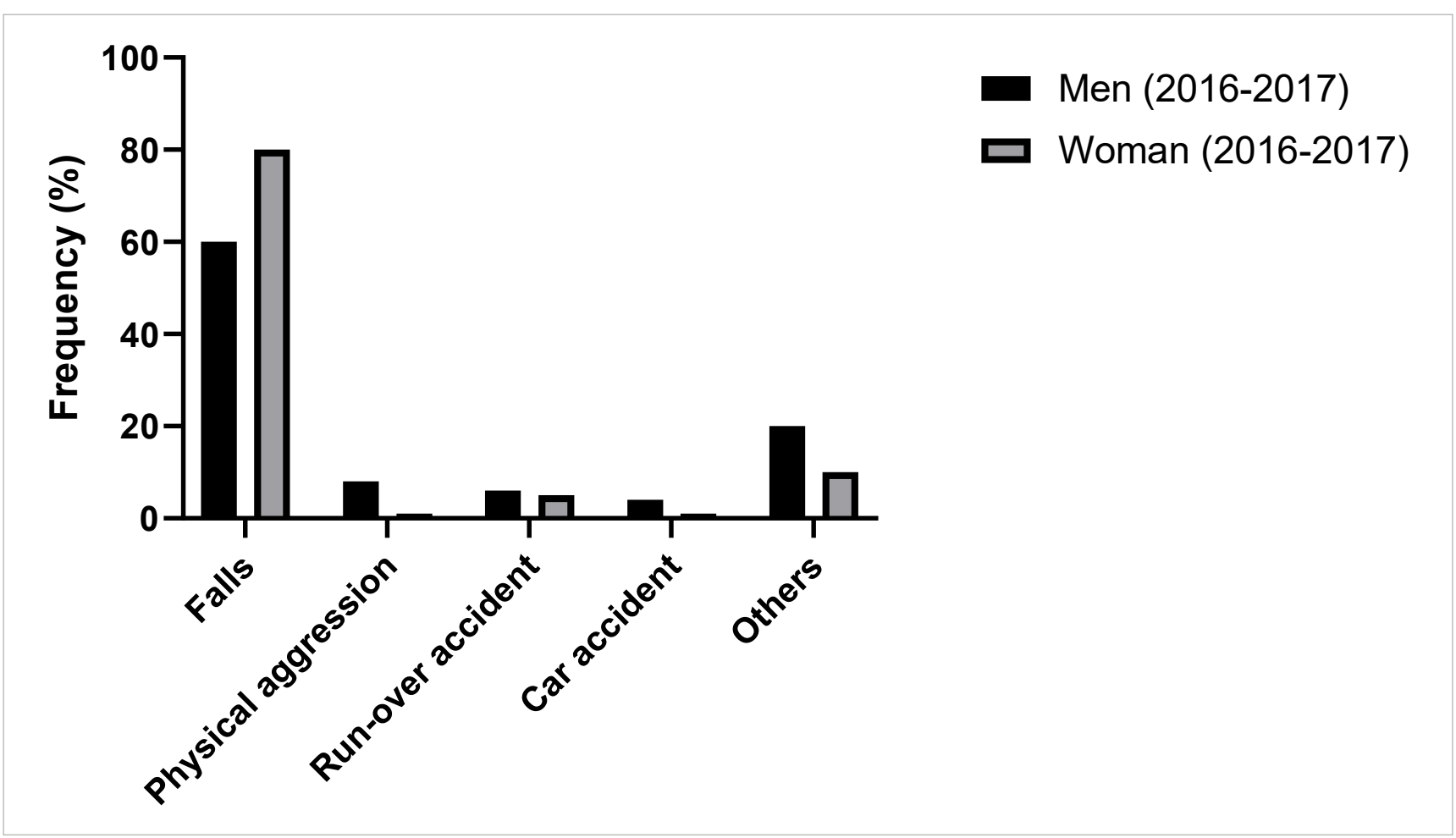

Figure 1. Etiology of trauma by gender and period (2016-2017). 
Table 2. Etiology of trauma categorized by age group and gender.

\begin{tabular}{|c|c|c|c|c|c|c|}
\hline \multirow{2}{*}{ Etiology of trauma } & \multicolumn{3}{|c|}{ Male (n) } & \multicolumn{3}{|c|}{ Female (n) } \\
\hline & $60-69$ & $70-79$ & $>80$ & $60-69$ & $70-79$ & $>80$ \\
\hline Fall & 23 & 10 & 9 & 20 & 13 & 9 \\
\hline Physical aggression & 7 & 1 & 2 & 1 & - & - \\
\hline Run-over accident & 5 & - & 1 & 3 & - & - \\
\hline Bicycle accident & 7 & 1 & - & - & - & - \\
\hline Car accident & 3 & 2 & 1 & 1 & - & - \\
\hline Sports accident & 2 & 1 & & & 1 & \\
\hline Pathological fracture & 2 & - & - & 1 & - & - \\
\hline Motorcycle accident & - & 1 & - & 2 & - & - \\
\hline Perforation by firearm & 1 & 2 & - & - & - & - \\
\hline Occupational accidents & 1 & 1 & & & & \\
\hline Animals & 1 & - & - & - & - & - \\
\hline Collision with fixed object & 1 & - & - & - & - & - \\
\hline Foreign object & 1 & - & - & - & - & - \\
\hline Hot object & 1 & - & - & - & - & - \\
\hline Bite & - & - & - & - & - & 1 \\
\hline Total (\%) & 55 & 19 & 13 & 28 & 14 & 10 \\
\hline
\end{tabular}

Source: elaborated by the authors, based on data from the Trackcare system of the Federal District State Health Department.

Table 3. Type of facial trauma categorized by age group and gender.

\begin{tabular}{|c|c|c|c|c|c|c|c|}
\hline \multirow{2}{*}{ Types of trauma } & \multicolumn{3}{|c|}{ Male } & \multicolumn{3}{|c|}{ Female } & \multirow{2}{*}{ Total } \\
\hline & $60-69$ & 70-79 & $>80$ & $60-69$ & $70-79$ & $>80$ & \\
\hline Facial contusion & 11 & 3 & 3 & 8 & 6 & 4 & 35 \\
\hline Mandible fracture & 12 & 1 & 2 & 7 & 1 & - & 23 \\
\hline Fracture of the zygomaticomaxillary complex & 4 & 3 & 5 & 4 & 4 & 2 & 22 \\
\hline Laceration of soft tissues & 7 & - & - & 2 & 2 & 2 & 13 \\
\hline Zygomatic arch fracture & 6 & 3 & - & - & - & 1 & 10 \\
\hline Maxillary fracture & 4 & 2 & 2 & 1 & - & - & 9 \\
\hline Dentoalveolar trauma & 2 & 1 & - & 3 & . & - & 6 \\
\hline $\begin{array}{l}\text { Fracture of the zygomaticomaxillary complex } \\
+ \text { orbit }\end{array}$ & 1 & 2 & - & - & 1 & - & 4 \\
\hline Orbit fracture & 1 & 2 & - & 1 & - & - & 4 \\
\hline Frontal fracture & 2 & - & 1 & - & - & 1 & 4 \\
\hline $\begin{array}{l}\text { Fracture of the maxilla }+ \\
\text { zygomaticomaxillary complex }\end{array}$ & 1 & 1 & - & 1 & - & - & 3 \\
\hline $\begin{array}{l}\text { Fracture of the mandible }+ \\
\text { zygomaticomaxillary complex }\end{array}$ & - & 1 & - & 1 & - & - & 2 \\
\hline Fracture of the mandible + maxilla & 1 & - & - & - & - & - & 1 \\
\hline Panfacial fracture & 1 & - & - & - & - & - & 1 \\
\hline Abrasion & 1 & - & - & - & - & - & 1 \\
\hline Burn & 1 & - & - & - & - & - & 1 \\
\hline Total & 55 & 19 & 13 & 28 & 14 & 10 & 139 \\
\hline
\end{tabular}

Source: elaborated by the authors, based on data from the Trackcare system of the Federal District State Health Department. 
Table 4. Treatment by age group and gender.

\begin{tabular}{|c|c|c|c|c|c|c|}
\hline \multirow{2}{*}{ Types of treatment } & \multicolumn{3}{|c|}{ Male } & \multicolumn{3}{|c|}{ Female } \\
\hline & $60-69$ & $70-79$ & $>80$ & $60-69$ & $70-79$ & $>80$ \\
\hline Surgical, without stable internal fixation & 2 & - & - & - & - & 1 \\
\hline Surgical, with stable internal fixation & 8 & 2 & 2 & 2 & - & - \\
\hline Conservative & 19 & 10 & 8 & 14 & 6 & 2 \\
\hline Containment & & - & - & 2 & - & - \\
\hline Evasion/not allowed & 4 & 1 & & 1 & - & - \\
\hline Guidance & 16 & 6 & 3 & 7 & 6 & 6 \\
\hline Private transfer & - & - & - & 1 & - & - \\
\hline Foreign object removal & 1 & - & - & - & - & - \\
\hline Suture & 5 & - & - & 1 & 2 & 1 \\
\hline Total & 55 & 19 & 13 & 28 & 14 & 10 \\
\hline
\end{tabular}

Source: elaborated by the authors, based on data from the Trackcare system of Federal District State Health Department.

\section{DISCUSSION}

Population aging has been one of the main topics addressed by health care services, whether public or private, in developing countries. Not only from the perspective of an impact on the economy, but of evident sociocultural transformations that the societies themselves will experience. Since older adults will comprise most of the economically active population, consequently being victims of aggressive agents of modern life, they become subject to trauma, including in the face. The face is an important anatomical structure for performing masticatory functions (stomatognathic system) that are fundamental in basic biological processes, beginning the digestion process, and for social interactions, with verbal communication. ${ }^{6,12}$

In this context and based on this analysis, gerontology professionals and maxillofacial surgeons should be prepared for this new reality, since particularities inherent to the systemic and locoregional aspects of the face (such as edentulism in older adults) alter and directly guide the choice of therapy and prognosis of facial trauma. ${ }^{12}$ In this sense, the literature is in line with our study and states that it is important to advance and value epidemiological and clinical studies in order to outline profiles that help policies and actions directed towards the older population., ${ }^{4,15}$

Based on the premise that trauma in the facial region often results in injuries to the soft tissue and major components of the skeleton in the face, a detailed understanding of the etiology, types, and surgical treatment of facial injuries are topics discussed in this work.

When analyzed by frequency, the number of cases of older patients in the IHBDF was $5.8 \%$, which is below the mean $8 \%$ observed in studies published in Brazil. ${ }^{13,16}$ Even with this discovery, it is important to highlight the number of cases over 2 years: 2384 cases of facial trauma, 139 of which were in older people. This is a significant sample, as it comes from a referral hospital in the Central-West region of Brazil. Our numbers match other epidemiological studies, such as those performed by Giacomin et al. ${ }^{15}$ and Grempel. ${ }^{17}$

In our study, as shown in Figure 1, falls were the main etiological agent for injuries in both men and women between 2016 and 2017; this is also in harmony with studies by Winstead et al. ${ }^{18}$ Giacomin et al., ${ }^{15}$ Ito et al., ${ }^{6}$ and Rezaei et al.; ${ }^{19}$ these studies also verified falls and men as the most frequent etiologic agent and most affected gender, respectively, differently from Grempel, ${ }^{17}$ Thomson et al. ${ }^{20}$ Brucoli et al. ${ }^{21}$ Burkhard et al. ${ }^{22}$

Another important point to be considered for the results of this work involves the lifestyle and habits related to aging, which predisposes older adults to domestic accidents and traumas with less kinetic energy while reducing the possibilities of trauma due to interpersonal violence and sports accidents. ${ }^{15} \mathrm{O}$ wing to the longer permanence of older adults in their homes, most falls result from domestic accidents, ${ }^{23}$ although their specifics were not verified in this study because of the limited data on medical records of patients assisted at the Emergency Department. Characteristics inherent to the aging process, such as decreased proprioception, changes in motor response, tremors, and decreased visual and auditory acuity can be mentioned as factors that predispose to a greater number of falls and stumbles. ${ }^{8,10}$

However, data referring to physical aggressions and car accidents must be highlighted, since these are causes of diverse trauma to the face, especially in men (and with statistical significance). It is noteworthy that physical aggression is a clinically important factor to be described in men, as well as in women, even if a significant percentage is not shown 
here. Nevertheless, it can be one of the main causes of facial trauma due to the increasing insertion of older adults in the economically active population, making this group increasingly exposed to different types of urban violence. ${ }^{24}$

Correia et al. ${ }^{25}$ in a study performed out at Hospital de Restauração in Recife (PE), reports older adults aged between 60 and 69 years as the group with the highest number of victims of physical violence and the diagnosis of facial contusion as the main type of facial trauma, corroborating data on Tables 1 and 2. Sousa ${ }^{24}$ draws special attention to facial trauma as a social marker of physical violence to the older population, especially men, by the adoption of risky behaviors. These data cannot be underestimated when verified in studies on this topic, highlighting and expressing a very characteristic social reality for the region or even the country.

Within the perspective of categorizing older adults' age groups regarding the frequency of injuries, we observed that for both men and women, the younger the patient, the greater the frequency of facial injuries. This can be explained by the greater number of older people at this age compared to other age groups, in addition to the fact that patients of this age group are generally more active, being exposed to many of the risk factors that the active adult population is exposed to. ${ }^{26,27}$ These specific characteristics explain variations found in the number of traumatic agents, especially among men.

As for the injury site, a higher frequency of facial contusions was verified, followed by fractures of the mandible and zygomatic complex. When considering the reviewed literature, facial contusion was defined as a diagnosis even if it did not involve bone structures. It was nevertheless considered important in the classification of facial injuries as a pathology that might require treatment; in the clinical cases in question, in emergency room care, the health professional should not neglect such assistance according to the established literature on maxillofacial traumatology..$^{12,27}$

In terms of bone fractures, a higher frequency of mandibular involvement was observed, followed closely by the zygomatic complex (16.5\% and $15.8 \%$, respectively). These numbers are different from those observed by Gassner et al., ${ }^{28}$ Wade et al., ${ }^{29}$ Velayutham et al., ${ }^{5}$ Imholz et al., ${ }^{30}$ and Giacomin et al., ${ }^{15}$ who showed fractures of the zygomatic complex as the most prevalent in older adults. Facial injuries predominantly affected men in comparison with women, with the exception of contusions, with very close numbers. From this analysis, it appears that men are more exposed to facial trauma in general, which is possibly explained by being exposed to work activities of higher risk. ${ }^{12}$

Regarding the treatment adopted for different types of facial trauma, a conservative pattern and local guidelines for men and women were preferred over more invasive therapies such as surgery, which is in accordance with the established literature as described by Fonseca. ${ }^{12}$ In this sense, functional issues were considered a fundamental criterion to determine the need for more invasive surgical procedures, since older adults tend not to be concerned with problems related to facial aesthetics only (as described by important works published in the area) ${ }^{6,15,17}$ According to Table 4, it is also evident that the conservative treatment was chosen regardless of the age group, which can be justified by the tendency of older adults to value functional aspects over aesthetic ones. ${ }^{15,17}$

\section{CONCLUSION}

After analyzing the data in this study, some conclusions were established:

1. Falls were the most important factor for both male and female patients, with women being more affected than men.

2. Contusion was the facial trauma with the highest prevalence among older adults studied in 2016 and 2017. When considering fractures, the mandible was the most affected site, with a greater frequency in men than in women.

3. Conservative treatment and local guidelines were the preferentially adopted therapeutic approaches for both female and male older adults. Surgical treatment with rigid internal fixation was more present in men than in women, in all age groups.

It is noteworthy that with the growth trend of the older population in the next decades, as well as their more active lifestyle (especially considering the group aged 60 to 69 years), older adults will be exposed to risk factors for facial trauma. This requires proper management and knowledge by gerontology professionals and oral and maxillofacial surgeons, since while the older population presents specific conditions and physiological changes with advancing age, they will continue to be active in society and consequently susceptive to various trauma mechanisms.

\section{CONFLICTS OF INTEREST}

The authors declare no conflicts of interest.

\section{FUNDING}

This research did not receive any specific grant from funding agencies in the public, commercial, or not-for-profit sectors. 


\section{AUTHORS' CONTRIBUTION}

MAB: investigation. DSP: conceptualization, data curation, formal analysis, funding acquisition, methodology, project administration, resources. AAGS: conceptualization, data curation, formal analysis, funding acquisition, methodology, project administration, software. LPMS: investigation. IGSR: investigation. ELSR: supervision. AFM: supervision. LOG: supervision.

\section{REFERENCES}

1. Gomes ECC, Marques APO, Leal MCC, Barros BP. Fatores associados ao risco de quedas em idosos institucionalizados: uma revisão integrativa. Ciênc Saúde Coletiva. 2014;19(8):3543-51. https://doi. org/10.1590/1413-81232014198.16302013.

2. Meneses EMS, Melo WF, Melo WF, Rodrigues LMS. Análise preventiva da incidência de traumas em idosos. Revista Brasileira de Educação e Saúde. 2016;6(3):34-8. https://doi.org/10.18378/rebes.v6i3.4481.

3. Oliveira TC, Medeiros WR, Lima KC. Diferenciais de mortalidade por causas nas faixas etárias limítrofes de idosos. Rev Bras Geriatr Gerontol. 2015;18(1):85-94. https://doi.org/10.1590/1809-9823.2015.14203.

4. Moura MTFL, Daltro, RM, Almeida, TF. Traumas faciais: uma revisão sistemática da literatura. RFO. 2016;21(3):331-7. http:// doi.org/10.5335/rfo.v21i3.6158.

5. Velayutham L, Sivanandarajasingam A, O'Meara C, Hyam D. Elderly patients with maxillofacial trauma: the effect of an ageing population on a maxillofacial unit's workload. $\mathrm{Br}$ j Oral Maxillofac Surg. 2013;51(2):128-32. https://doi.org/10.1016/j.bjoms.2012.05.003.

6. Ito R, Kubota K, Inui A, Nakagawa H, Kon T, Narita N, et al. Oralmaxillofacial trauma of a geriatric population in a super-ageing country. Dent Traumatol. 2017;33(6):433-7. https://doi.org/10.1111/ edt.12371.

7. Carvalho Filho MAM, Saintrain MVL, Dos Anjos RES, Pinheiro SS, Cardoso LCP, Moizan JAH, et al. Prevalence of oral and maxillofacial trauma in elders admitted to a reference hospital in northeastern Brazil. PLoS One. 2015;10(8):e0135813. https://doi.org/10.1371/ journal.pone.0135813.

8. Yildiz M, Bozdemir MN, Kiliçaslan I, Ateşçelik M, Gürbüz S, Mutlu B, et al. Elderly trauma: the two years experience of a universityaffiliated emergency department. Eur Rev Med Pharmacol Sci. 2012;16 Suppl 1:62-7. PMID: 22582487

9. Toivari M, Suominen AL, Lindqvist C, Thorén H. Among patients with facial fractures, geriatric patients have an increased risk for associated injuries. J Oral Maxillofac Surg. 2016;74(7):1403-9. https://doi.org/10.1016/j.joms.2016.02.001

10. Pham-Dang N, Barthélémy I, Orliaguet T, Artola A, Mondié IM, Dallel R. Etiology, distribution, treatment modalities and complications of maxillofacial fractures. Med Oral Patol Oral Cir Bucal. 2014;19(3):e261-9. https://doi.org/10.4317/medoral.19077

11. Gasparotto LPR, Falsarella GR, Coimbra AMV. As quedas no cenário da velhice: conceitos básicos e atualidades da pesquisa em saúde. Rev Bras Geriatr Gerontol. 2014;17(1):201-9. https://doi.org/10.1590/ S1809-98232014000100019.

12. Fonseca RJ. Trauma bucomaxilofacial. 4th. ed. São Paulo: Elsevier; 2015.

13. Araújo CFSN, Braga PLS. Epidemiologia do trauma maxilofacial num hospital terciário da cidade de Macapá. Rev Bras Cir Cabeça Pescoço [Internet] 2016 [Accessed in 2021 aug 15;45(4):121-5. Availabble in: http://www.sbccp.org.br/wp-content/uploads/2016/07/ Rev-SBCCP-45-4-artigo02.pdf.

14. Barber HD. Conservative management of the fractured atrophic edentulous mandible. J Oral Maxillofac Surg. 2001;59(7):789-91. https://doi.org/10.1053/joms.2001.24734.

15. Giacomin M, Conto F, Siqueira SP, Signori PH, Eidt JMS, Sawazaki R. Trauma facial em idosos: uma análise retrospectiva de 10 anos. Rev Bras Geriatr Gerontol. 2017;20(5):618-24. https://doi. org/10.1590/1981-22562017020.160183.
16. Ykeda RBA, Ballin CR, Moraes RS, Ykeda RBA, Miksza AF. Epidemiological profile of 277 patients with facial fractures treated at the emergency room at the ENT Department of Hospital do Trabalhador in Curitiba/ PR, in 2010. Int Arch Otorhinolaryngol. 2012;16(4):437-44. https:// doi.org/10.7162/S1809-97772012000400003.

17. Grempel RG. Traumatismos faciais em pacientes idosos atendidos pela Faculdade de Odontologia de Piracicaba [dissertação]. Piracicaba: Universidade Estadual de Piracicaba; 2008.

18. Winstead ML, Clegg DJ, Heidel RE, Ledderhof NJ, Gotcher JE. Fallrelated facial trauma: a retrospective review of fracture patterns and medical comorbidity. J Oral Maxillofac Surg. 2021;79(4):864-70. https://doi.org/10.1016/j.joms.2020.09.040.

19. Rezaei M, Jamshidi S, Jalilian T, Falahi N. Epidemiology of maxillofacial trauma in a university hospital of Kermanshah, Iran. Journal of Oral and Maxillofacial Surgery Medicine and Pathology. 2017;29(2):1 10-5. https://doi.org/10.1016/j.ajoms.2016.09.008.

20. Thomson WM, Stephenson S, Kieser JA, Langley JD. Dental and maxillofacial injuries among older NewZealanders during the 1990s. IntJ Oral Maxillofac Surg. 2003;32(2):201-5. https://doi.org/10.1054/ijom.2002.0373.

21. Brucoli M, Boffano P, Romeo I, Corio C, Benech A, Ruslin M, et al. Epidemiology of maxillofacial trauma in the elderly: a European multicenter study. J Stomat Oral Maxillofac Surg. 2020;121(4):33038. https://doi.org/10.1016/j.jormas.2019.09.002.

22. Burkhard JPM, Pitteloud C, Klukowska-Rötzler J, Exadaktylos AK, lizuka T, Schaller B. Changing trends in epidemiology and management of facial trauma in a Swiss geriatric population. Gerodontology. 2019;36(4):358-64. https://doi.org/10.1111/ger.12410.

23. Kloss FR, Tuli T, Hächl O, Laimer K, Jank S, Stempfl K, et al. The impact of ageing on cranio-maxillofacial trauma: a comparative investigation. Int J Oral Maxillofac Surg. 2007;36(12):1158-63. https://doi.org/10.1016/j.ijom.2007.07.009.

24. Sousa RIM. Traumas faciais como marcadores de violência física contra idosos [dissertação]. Campina Grande: Universidade Estadual da Paraíba; 2015.

25. Correia TMP, Leal MCC, Marques APO, Salgado RAG, Melo HMA Perfil dos idosos em situação de violência atendidos em serviço de emergência em Recife-PE. Rev Bras Geriatr Gerontol. 2012;15(3):52936. http://doi.org/10.1590/S1809-98232012000300013.

26. Wulkan M, Parreira Jr JG, Botter DA. Epidemiologia do trauma facial. Rev Assoc Med Bras. 2005;51(5):290-5. https://doi.org/10.1590/ S0104-42302005000500022

27. Eidt JMS, Conto F, Bortoli MM, Engelmann JL, Rocha FD. Associated injuries in patients with maxillofacial trauma at the hospital São Vicente de Paulo, Passo Fundo, Brazil. J Oral Maxillofac Res. 2013;4(3):e1. https://doi.org/10.5037/jomr.2013.4301

28. Gassner R, Tuli T, Hächl O, Rudisch A, Ulmer H. Cranio-maxillofacial trauma: a 10 year review of 9,543 cases with 21,067 injuries. J Craniomaxillofac Surg. 2003;31(1):51-61. https://doi.org/10.1016/s1010-5182(02)00168-3

29. Wade CV, Hoffman GR, Brennan PA. Falls in elderly people that result in facial injuries. Br J Oral Maxillofac Surg. 2004;42(2):13841. https://doi.org/10.1016/S0266-4356(03)00256-0

30. Imholz B, Combescure C, Scolozzi P. Is age of the patient an independent predictor influencing the management of cranio-maxillo-facial trauma? A retrospective study of 308 patients. Oral Surg Oral Med Oral Pathol Oral Radiol. 2014;117(6):690-6. https://doi.org/10.1016/j.000o.2014.03.010 